\title{
Their Day in Court
}

\section{Assessing Guilty Plea Rates Among Terrorists}

Christopher A. Shields

University of Arkansas, Fayetteville

Kelly R. Damphousse

University of Oklahoma, Norman

Brent L. Smith

University of Arkansas, Fayetteville

Individuals who are charged for traditional crimes are substantially more likely to plead guilty than individuals who are charged under the same statutes but who are officially involved in terrorism (Smith \& Damphousse, 1998). Relying on a structural-contextual theory framework, a quantitative analysis not only confirmed that terrorists plead guilty more often than traditional offenders but that the defendant's age and number of counts in the indictment are important predictors. Directions for future research are suggested.

\section{Keywords: terrorism; plea bargain; structural-contextual}

\begin{abstract}
A cademicians, politicians, and lawyers have long debated the merits of plea bargaining, and most studies have had at least one common thread-the percentage of defendants pleading guilty in federal and state criminal cases has remained significant, typically higher than $80 \%$ (e.g., Champion, 1989; Smith, 1994). ${ }^{1}$ All court actors have incentives to negotiate dispositions rather than take cases to trial because "trials are slow and unpredictable, they require prodigious investment of resources and preparation, and they produce one winner and one loser, with no room for compromise" (Worden, 1990, p. 335).

Research conducted by Smith (1994) and by Smith and Damphousse (1996, 1998) revealed that terrorists plead guilty at half the percentage of traditional criminal defendants. Indeed, terrorists are unlike traditional offenders in many fundamental ways. Terrorists do not fit the typical demographic profile of common criminals;

Authors' Note: Portions of this research were funded by the National Institute of Justice (Grant Number 1999-IJCX-0005) and the Oklahoma City National Memorial Institute for the Prevention of Terrorism (MIPT; Grant Number MIPT 106-113-2000-064) through the Department of Justice and the Department of Homeland Security. The opinions presented here do not represent the official position of the Department of Justice, the Department of Homeland Security, the MIPT, or the National Institute of Justice. Direct correspondence to Brent L. Smith, Terrorism Research Center in Fulbright College, 211 Old Main, University of Arkansas, Fayetteville, AR 72701 or e-mail at bls@uark.edu.
\end{abstract}


terrorists are motivated by political or social goals instead of pecuniary ones; and their behavior is significantly different from traditional offenders following arrest and indictment-including a much lower plea rate. To address this issue, it is important to look at plea bargain literature in an effort to better understand crime-specific pleading patterns.

There is a wealth of literature concerning the merits of negotiated pleas, but by comparison, there has been little research dedicated toward an understanding of the theoretical underpinnings of plea bargains. To some, the problem inherent in plea bargaining is the illusiveness of the decision-making process (Harris \& Springer, 1984; Lagoy, Senna, \& Siegel, 1976). The existing research has generally emerged from two directions: (a) studies focused directly on factors that affect decision making and (b) studies that measure the effect of legal and extra-legal variables on the plea-bargain rate. ${ }^{2}$

\section{Decision-Centered Studies}

Evolving from attempts to understand the illusive nature of plea decision making, decision-centered methodologies are the product of data obtained by conducting interviews and surveys, distributing questionnaires, and engaging in participant observation that is directly focused on the perceptions of judges, prosecuting attorneys, and defense counsel (Buckle \& Buckle, 1977; Heumann, 1977; Mather, 1979; McAllister, 1990; Meyer \& Gray, 1997; Parnas, 1979; Worden, 1990; Utz, 1977). An example of this approach is Emmelman's recursive decision-making theory, wherein she examines the interplay of numerous variables among three activities that the study uses to define the decision-making process (Emmelman, 1996). According to recursive decision making, the first activity involves defense attorneys who estimate the value of a case by deciding whether it might be won or lost at trial. Estimates result in three tentative conclusions: Many cases should be plea bargained immediately; some should proceed further; others should go to trial. The defense attorney's tacit understanding of the value of a case actively structures his or her negotiation techniques, and it is the process of negotiating the terms of a plea that forms the second activity in recursive decision making. The final activity requires the attorney to counsel the defendant and decide on a course of action. The defense attorney repeatedly engages in these activities until reaching a settlement or until the case is resolved by trial (Emmelman, 1996).

Harris and Springer (1984) evaluate similar studies (Lagoy et al., 1976; Newman, 1966; White, 1971) and conclude that prior research involved a shotgun approach of looking at too many variables leading to deficiencies in theoretical reliability. Alternatively, they build on research by Simon (1976) and suggest a model that focuses on decision making as a two-person game between an agent for the statethe prosecutor-and an agent for the defendant-the defense attorney (Harris \& Springer, 1984).

Harris and Springer (1984) identify four factors that shape decision making: the evidentiary strength of the defendant's case, which involves court actors evaluating the 
reliability of physical evidence and witnesses; ${ }^{3}$ the seriousness of the crime charged; the defendant's criminal record; and extra-legal variables such as gender and race. They argue that plea negotiations are not the result of carefully balancing multiple pieces of information, but rather the result of constrained negotiations, dominated by rules of thumb developed by both agents (Harris \& Springer, 1984). Their analysis of California robbery and burglary cases leads them to conclude that plea bargaining is dominated by standard operating procedures and the study finds that prior criminal history has the strongest effect with a negative relationship on whether a case is settled by plea bargain (Harris \& Springer, 1984)

A study of prosecutors in Georgia Superior Courts asserts that plea bargaining rates are dependent on the politics and attitudes that exist within individual jurisdictions, rather than on the resources available to prosecutors (Worden, 1990). ${ }^{4}$ This study asserts that prosecutors are more willing to negotiate a plea when they exert some impact on sentence outcomes, suggesting that prosecutors are not as likely to negotiate a settlement when judges routinely follow the presentence investigation recommendations on sentence length rather than the prosecutors' recommendations. Prosecutors' policies toward plea bargaining are shaped by the perceived needs of the community - in jurisdictions where crime is a genuine problem, plea bargaining policies become more restrictive (Worden, 1990).

Other research on prosecutorial discretion has explored a number of factors that affect plea bargain rates (Alschuler, 1975; Champion 1987, 1989; Frazier \& Bock, 1982; Klein, 1976). Many prosecutors have gathered socioeconomic background information on various defendants, including Internal Revenue Service information (Champion, 1987). Some prosecutors gather data on defendants' criminal history, marital status, and their ability to obtain quality legal representation (Champion, 1989; LaFave, 1978; Lagoy, Hussey, \& Kramer, 1979; Mather, 1979). Studies revealed that $60 \%$ of prosecutors would intensify the punitive severity of a plea offer if the crime was violent and committed against persons, but notably, only $34 \%$ of prosecutors would intensify punitive severity when they believed they had strong evidence (Champion, 1989). According to this study, strength of evidence had the strongest effect on whether a prosecutor pursued cases or dropped them. Similarly, $82 \%$ of prosecutors would decrease punitive severity in plea bargains if they believed the evidence against the defendant was weak, and $46 \%$ would decrease severity if the defendants were first-time offenders (Champion, 1989).

Champion's (1989) findings support Harris and Springer's (1984) rule of thumb theory. The study found that prosecutors had a going rate for virtually every kind of criminal offense (Champion, 1989). Champion also found that defendants with private attorneys were less likely to accept the going rate and more likely to get shorter offers than do defendants with public defenders. Indeed, this study revealed that defendants who hired private attorneys were more likely to go to trial than defendants represented by public defenders (Champion, 1989). ${ }^{5}$

McAllister and Bregman (2001) evaluated the responses of role-playing defendants and role-playing defense attorneys. They found that as the probability of conviction 
increases, both defendants and defense attorneys were more likely to pursue a guilty plea. Conversely, as sentence severity increased only the defendants were more receptive to pleading guilty. ${ }^{6}$ In other words, defendants who faced a potential sentence of more than 5 years were more receptive to a plea bargain, to mitigate their potential sentence, than defendants who faced a possible sentence of 2 years (McAllister \& Bregman, 2001).

\section{Analysis of Legal and Extra-Legal Variables}

In a study to measure the effect of legal and extra-legal variables on the rate of plea bargains, LaFree (1980) analyzed rape cases and found that plea bargain rates were affected by evidentiary variables: As the amount of evidence available to the prosecutor increases, so does the probability of a guilty plea. Similarly, as the number of witnesses available to the prosecutor increases, so does the probability of a guilty plea. ${ }^{7}$ LaFree's findings are consistent with decision-centered theories (e.g., Harris \& Springer, 1984; Emmelman, 1996), predicting that defendants with a lower case value are more likely to plead guilty. Similarly, Albonetti (1990) found that defendants were much more likely to plead guilty where evidence against them was strong.

Meyer and Gray (1997) evaluated legal and extra-legal factors on guilty plea rates in drunk driving arraignments, finding that drivers facing more serious charges were more likely to plead not guilty at arraignment. Although their research did not reflect the number of defendants who might plead guilty prior to trial, it is consistent with prior research-recidivists, and those facing longer prison terms, are less likely to plead guilty (Albonetti, 1990). Additionally, those facing serious charges in lower courts are less likely to plead guilty (Brickey \& Miller, 1975; Mileski, 1971). Meyer and Gray (1997) found that gender did not affect the decision to plead guilty, although race did —Caucasians were less likely to plead guilty than minorities. This finding is similar to those of LaFree (1980). ${ }^{8}$ Interestingly, the study did not find that criminal history affected guilty pleas, but the authors point out the likelihood that this finding was the result of low sample size. ${ }^{9}$

Albonetti (1990) found that the existence of physical evidence, an increase in the number of charges, and the defendant's confession to the crime during police and prosecutor interrogation increased the probability of a guilty plea. The number of witnesses, use of a weapon, and offenses carrying a minimum penalty of 5 years (with no maximum prison term) decreased the probability of a guilty plea. Recidivists and those facing longer prison sentences were less likely to plead guilty. The effect of marital status, prior record of felony convictions, type of counsel, number of charges, and use of a weapon on the probability of a guilty plea varied according to defendant's race. When controlling for offense severity, prior record, presence of physical evidence, eyewitness identification, pretrial release, type of 
counsel, and whether the defendant confessed, Albonetti (1990) found that black defendants were less likely than Caucasians to plead guilty in felony cases.

Wooldredge (1989) provides another approach to plea bargain rates. By analyzing guilty pleas (for similar felony charges) in 269 jurisdictions (across seven states), Wooldredge found a curvilinear relationship between the size of jurisdiction (and city size) and the rate of felony guilty pleas. The guilty plea rate increases as jurisdiction size increases. The rate increases more gradually as jurisdiction size moves from small—around 1,000 people—-to medium-sized jurisdictions of 50,000 people. Wooldredge notes the guilty plea rate levels off at the medium-sized jurisdiction level and remains relatively unchanged as jurisdiction size increases to large. The same relationship exists between city size and guilty plea rate, although Wooldredge claims that jurisdiction size is a better predictor of variation than city size. The relationship between caseload and rate of guilty plea is positive until caseload reaches 600 to 700 . At that level, the guilty plea decreases until caseload reaches 1,300 cases and then the relationship once again becomes positive (Wooldredge, 1989).

In a study focused on white-collar crimes, Albonetti (1998) combined the uncertainty avoidance perspective, ${ }^{10}$ and an understanding of the legalities of pleading guilty, to theorize that guilty pleas vary in their worth to prosecuting attorneys because of an interplay between legality, bureaucratic interests, finality in case processing, and case complexity. This legal-bureaucratic theory (Albonetti, 1998) suggests that negotiating power shifts from the prosecutor to the defendant in complex white-collar crimes, allowing the defendant to negotiate a shorter sentence. In this study, an overarching plan of illegal activity or a high level of organization characterizes case complexity. These complex white-collar crimes are categorically different from other crime because of the absence of presumptive evidence of a crime (Albonetti, 1998).

\section{Structural-Contextual Theory}

Research conducted prior to this study has been helpful in shaping our understanding of plea bargain rates but lacked the factors that effectively differentiate terrorist defendants from nonterrorist defendants. Terrorists are treated differently than nonterrorists, and prior research has indicated that terrorists are convicted by trial more often than nonterrorists (Smith \& Damphousse, 1996, 1998). Of the aforementioned studies, Worden's (1990) research is unique in that it is focused on the political environment surrounding plea decisions in separate Georgia court jurisdictions. In contrast, terrorists are convicted in federal courts across the nation (Smith \& Damphousse, 1996, 1998), and many courts may not docket more than one or two cases in as many years, making jurisdictional analysis such as Worden's impractical and unreliable. A theory that accounts for the political environment that surrounds terrorism cases is necessary.

Focusing on unexplained variances in sentencing, Hagan, Nagel, and Albonetti (1980) advanced the proposition that researchers could predict sentence outcomes 
Table 1

Typology of Explained Variance in Sentence Outcomes

\begin{tabular}{lll}
\hline \multirow{2}{*}{ Proactive Political Environment } & \multicolumn{2}{c}{ Crime Severity } \\
\cline { 2 - 3 } Nonterrorist & \multicolumn{1}{c}{ Low } & High \\
Terrorist & $\begin{array}{l}\text { a) Low levels of explained } \\
\text { variance }\end{array}$ & $\begin{array}{l}\text { b) Moderate levels of explained } \\
\text { variance }\end{array}$ \\
& $\begin{array}{l}\text { c) Moderate levels of explained } \\
\text { variance }\end{array}$ & $\begin{array}{l}\text { d) High levels of explained } \\
\text { variance }\end{array}$ \\
\hline
\end{tabular}

Source: Reprinted from Smith and Damphousse (1998).

more accurately for some crimes than others by using structural-contextual theory. He contends that disparity in sentences for offenses on which the government concentrates law enforcement and prosecutorial resources is substantially lower than it is for crimes escaping such scrutiny. Hagan (1989a, 1989b) hypothesized that studies of sentence outcomes focusing on crimes that are general in nature, or studies that do not concentrate on crimes that elicit intense federal response, will result in low levels of explained variance.

Components of the American criminal justice system tend to be loosely coupled, which leads to a decrease in explained variance (Hagan, 1989a). Even then, law officers and prosecutors may have resources to exchange, leading to a tighter coupling than normal. Structural-contextual theory suggests that when "political power is directed toward particular crime-linked goals," the American criminal justice system and subsystems tighten through the use of proactive techniques (Hagan, 1989a, p. 118). Hagan (1989a) further suggests that it is a proactive political environment that mandates a departure from normal criminal justice operations and that these departures involve the imposition of political power that sometimes targets the prosecution of a particular form of crime and criminal.

Smith and Damphousse (1998) applied structural-contextual theory to their research on terrorist or nonterrorist offenses. Terrorists convicted under the FBI's Counterterrorism Program are representative of offenders who are the focus of a proactive political environment via the government's expenditure of resources and personnel geared toward the terrorists' arrest and prosecution, similar to Hagan's drug and white-collar crime offenders (Smith \& Damphousse, 1998). Applying structural-contextual theory to terrorist or nonterrorist offenses, Smith and Damphousse (1998) suggest that when

a criminal act is officially designated by the polity as an act of terrorism, that designation sets in motion proactive law enforcement and prosecutorial techniques with concomitant increases in expenditures by law enforcement, prosecutorial, and judicial agencies. (p. 73) 
Table 2

Expected Plea Bargain Rates by Offense Level

\begin{tabular}{lll}
\hline $\begin{array}{l}\text { Proactive Political } \\
\text { Environment }\end{array}$ & \multicolumn{1}{c}{ Low Severity Offense } & \multicolumn{1}{c}{ High Severity Offense } \\
\hline No (Nonterrorist) & $\begin{array}{l}\text { a) Higher likelihood of a conviction } \\
\text { by guilty plea }\end{array}$ & $\begin{array}{l}\text { b) Moderate likelihood of a conviction } \\
\text { by guilty plea }\end{array}$ \\
Yes (Terrorist) & $\begin{array}{l}\text { c) Moderate likelihood of a conviction } \\
\text { by guilty plea }\end{array}$ & $\begin{array}{l}\text { d) low likelihood of a conviction } \\
\text { by guilty plea }\end{array}$ \\
\hline
\end{tabular}

It follows that one should be able to apply structural-contextual theory to help explain why terrorist defendants tend to plead guilty much less often than nonterrorist defendants. As with disparity in sentence outcomes, the likelihood of prosecutorial discretion would diminish in terrorism cases where there exists a proactive political environment geared toward the apprehension and conviction of terrorist defendants.

Thus, in the presence of a proactive political environment, prosecutors are less likely to exercise discretion in cases where the defendant has been identified as having committed a terrorism offense. Consequently, terrorists would experience diminished plea bargain opportunities. As a result, we expect that terrorists will be less likely to be convicted as a result of a guilty plea than similarly situated nonterrorists. This hypothesis is tested while controlling traditional variables that are typically used to explain the likelihood of a conviction by guilty plea.

\section{Methodology}

\section{Sample}

In the early 1980s, the FBI's Terrorist Research and Analytical Center published an annual report that specified which crimes were investigated under the FBI's Counterterrorism Program. At the time, this was the only public record of terrorism investigations in the United States. In 1989, the FBI released to Brent Smith the names of persons indicted as a result of these investigations for the period of 1980 through 1988 (Smith, 1994). Staff from the Department of Justice matched the list of terrorist indictees with federal court docket numbers assigned throughout the Unites States and Puerto Rico. Demographic and sentencing data were collected in each of the federal district courts where the trials occurred. The data were also supplemented by information provided by the Administrative Office of the U.S. Courts. ${ }^{11}$ This dataset became known as the American Terrorism Study (ATS) data (Damphousse \& Smith, 2004). The project team continuously added to ATS data 
during the years whenever the FBI released a new set of names to the project director. The terrorists who are examined in this analysis were provided by the FBI in a series of releases to the ATS project during a series of years and included people who were convicted as a result of a federal terrorism investigation from 1989 through 2002. The complete database of people who were indicted as a result of a terrorism database from 1980 to 2002 included data on more than 500 individuals. Since data collection after 1998 was incomplete, we limited the terrorist sample to persons who were convicted as a result of a terrorism investigation from 1990 to 1998.

The purpose of the current study was to examine the different experiences that terrorist indictees face during the pretrial phase concerning decisions about plea bargaining compared with similarly situated nonterrorists. To accomplish this task, it was imperative that we create a comparison group that was as similar as possible to the terrorists in our database and then to apply the appropriate statistical controls to allow for such a comparison. Thus, we matched each of the terrorists in our sample with five traditional offenders (i.e., nonterrorists) whose data were extracted from the Federal Judicial Center's Federal Court Cases Integrated Data Base.

Each of the terrorists was matched with all of the nonterrorists by (a) year of indictment and (b) offense code. Then, we randomly selected a sample of five nonterrorists who were indicted within the same year and for the same offense code categories for each of the terrorists, resulting in a 5:1 ratio of nonterrorists to terrorists. If an adequate number of nonterrorists could not be identified in the same year, persons convicted of the same offense were selected from adjacent years until the ratio was achieved. We selected a greater number of nonterrorists so that we could minimize some of the sampling error that would have occurred had we only matched convicted terrorists and nonterrorists on a 1:1 ratio. Selecting five nonterrorists will mitigate against the problem of selecting outliers into the nonterrorist sample.

We excluded 15 cases that involved explicitly politicized offenses (e.g., treason or sedition and national defense) because it was impossible to match them with nonterrorists who were charged with the same offense. In addition, 6 terrorists were convicted twice during the time period. Listwise deletion due to missing data resulted in a data set with 584 federally convicted felons (490 nonterrorists and 94 terrorists). Although the ATS contains more than 80 variables on each of the terrorists in the sample, it did not, by definition, contain any data on the nonterrorists in the sample that we created. Thus, to maintain consistency in measurement and coding, we used the Federal Sentencing Commission data for all of the analyses reported in the article.

\section{Variables}

The dependent variable in this study is conviction via a trial. The federal sentencing data provide two categories of conviction type: convicted at trial and convicted 
Table 3

Descriptive Statistics for Variables Used in Analyses $(N=584)$

\begin{tabular}{|c|c|c|c|c|c|}
\hline Variable & $n$ & $\%$ & Range & $M$ & $S D$ \\
\hline \multicolumn{6}{|l|}{ Conviction type } \\
\hline Convicted by trial & 97 & 16.6 & & & \\
\hline Convicted by guilty plea & 487 & 83.4 & & & \\
\hline \multicolumn{6}{|l|}{ Type of defendant } \\
\hline Nonterrorist & 490 & 83.9 & & & \\
\hline Terrorist & 94 & 16.1 & & & \\
\hline Age & & & 18 to 98 & 35.10 & 11.00 \\
\hline \multicolumn{6}{|l|}{ Minority status } \\
\hline Minority & 187 & 32.0 & & & \\
\hline White & 397 & 68.0 & & & \\
\hline \multicolumn{6}{|l|}{ Gender } \\
\hline Male & 513 & 87.8 & & & \\
\hline Female & 71 & 12.2 & & & \\
\hline \multicolumn{6}{|l|}{ Education } \\
\hline Less than high school & 168 & 28.8 & & & \\
\hline High school or GED & 199 & 34.1 & & & \\
\hline Some college & 172 & 20.9 & & & \\
\hline College grad & 45 & 7.7 & & & \\
\hline Number of counts in indictment & & & 1 to 50 & 1.97 & 3.12 \\
\hline Number of criminal history points & & & 0 to 27 & 3.00 & 4.32 \\
\hline
\end{tabular}

by guilty plea. Those who were convicted by trial were coded 1, whereas those who were convicted via a guilty plea were coded 0 .

All participants in this study were coded into the dummy variable called terrorist. Individuals who originated in the ATS study were coded 1, whereas persons who were selected in the matched nonterrorist sample were coded 0 . To control for factors that could affect the likelihood of a plea agreement's being reached, we also included the following control variables: number of counts (which reflects the number of counts that are included in each indictment) and criminal history (a scale variable that reflects the number of criminal history points that were used in the calculation of the potential penalty range).

To test variables specifically identified in the decision-centered studies, the variables race, gender, education, and age are included as measures of extralegal factors on the likelihood of a conviction occurring as a result of a criminal trial. Data on each of the variables used in the analysis are presented in Table 3.

Although previous studies have suggested that jurisdiction size is an important consideration in the likelihood of a conviction by guilty plea (Wooldredge, 1989), we did not include that variable because it was not in the data set. Although this variable could have been created, we decided not to include it because the majority of federal trials occur in jurisdictions much larger than 50,000. Because the effect of jurisdiction size 
Table 4

Bivariate Comparison of Case Disposition for Terrorists and Nonterrorists

\begin{tabular}{lllllrr}
\hline & \multicolumn{2}{c}{ Terrorists } & & \multicolumn{2}{c}{ Nonterrorists } & \\
\cline { 2 - 3 } \cline { 5 - 6 } & $n$ & $\%$ & & $n$ & $\%$ & $N$ \\
\hline Convicted by trial & 28 & 29.8 & & 69 & 14.1 & 97 \\
Convicted by guilty plea & 66 & 70.2 & & 421 & 85.9 & 487 \\
Total & 94 & & & 490 & & 618 \\
\hline
\end{tabular}

Chi-square $=14.05(p<.000)$.

seems to be greatest for jurisdictions between 1,000 and 50,000 people, we did not believe it would be necessary to include this control variable. In addition, information on the type of defense counsel (private or public defender) and case value ${ }^{12}$ (Emmelman, 1996; Harris \& Springer, 1984) is available in the ATS data and could have been incorporated into this analysis. Unfortunately, the information is not available in the federal sentencing data and it is therefore not available for the nonterrorists in our sample.

\section{Findings}

A bivariate analysis of the data was conducted to assess the difference between the percentage of terrorists and nonterrorists who were convicted via trial. The analysis shown in Table 4 reveals that the terrorists in this sample were twice as likely as nonterrorists to be convicted as a result of criminal trial (29.8\% and $14.1 \%$, respectively). This relationship is significant. It is important to note that the matching process implicitly controls for severity of offense and year of indictment.

Having determined that a relationship exists between type of defendant and how the conviction was determined, we now move to a multivariate analysis that will allow us to control for the effect of demographic variables and relevant case information that could affect the likelihood of a conviction occurring as a result of a guilty plea. Because the dependent variable is dichotomous (conviction by guilty plea $=0$, conviction by trial $=1$ ), we test our hypothesis using a logistic regression model. Our analyses are presented in Table 5. Please keep in mind that the matching procedure also means that we are controlling for severity of offense and year of indictment in each of the models presented in the table.

In Model I, we observe the effect of being indicted as a result of a terrorism investigation. This model effectively replicates the findings presented in Table 4 . Terrorists are more than twice as likely to be convicted as a result of a criminal trial than nonterrorists (odds ratio $=2.59, \mathrm{sig}=.000$ ). This suggests that terrorists are either less likely to accept a plea bargain offer or are less likely to be offered an offer 
Table 5

Logistic Regression Analysis Predicting the Likelihood of a Conviction as a Result of a Trial $(N=584)$

\begin{tabular}{|c|c|c|c|c|c|c|}
\hline \multirow[b]{2}{*}{ Variables } & \multicolumn{2}{|c|}{ Model I } & \multicolumn{2}{|c|}{ Model II } & \multicolumn{2}{|c|}{ Model III } \\
\hline & $B$ & Odds Ratio & $B$ & Odds Ratio & $B$ & Odds Ratio \\
\hline Terrorist & $0.95 *$ & 2.59 & $0.84 *$ & 2.32 & $0.80 *$ & 2.22 \\
\hline Age & & & $0.03^{*}$ & 1.03 & 0.03 & 1.03 \\
\hline Minority & & & 0.24 & 1.27 & 0.13 & 1.04 \\
\hline Education & & & 0.03 & 1.03 & 0.00 & 1.00 \\
\hline Male & & & 0.23 & 1.26 & 0.20 & 1.02 \\
\hline Criminal history & & & & & 0.02 & 1.02 \\
\hline Number of counts & & & & & $0.13^{*}$ & 1.14 \\
\hline Constant & -1.081 & & -3.260 & & -3.450 & \\
\hline-2 log likelihood & 512.8 & & 503.5 & & 488.5 & \\
\hline Nagelkerke $R^{2}$ & 0.035 & & 0.061 & & 0.103 & \\
\hline
\end{tabular}

$* p<.000$.

that they deem to be acceptable. In Model II, we assess the effect that demographic variables have on this relationship. Of the control variables, only age is statistically significant-as age of defendant increases, the likelihood of being convicted as a result of a trial increases (holding other variables constant). For this model, age is probably acting as a surrogate measure of criminal history and recidivism. This would be consistent with previous research (Albonetti, 1990). The effect of having been indicted as a result of a terrorism investigation is still significant after adding the demographic controls (odds ratio $=2.32$, sig $=.000$ ). Finally, in Model III, we add two case-specific variables that could affect the likelihood of a conviction by guilty plea. There is no significant effect of prior criminal history on the type of case disposition. On the other hand, there is a significant effect on the number of counts in the indictment. As the number of counts in the indictment increases, the likelihood of a conviction resulting from a trial significantly increases. The result is the opposite of Albonetti's (1990) observation that the number of charges pending against the defendant indirectly increases the likelihood of a plea bargain. This difference can probably be explained by the fact that we are controlling for count severity in this study. As in the previous two models, however, the effect of being indicted as a terrorist is still significant (odds ratio $=2.22$, sig $=.000$ ).

\section{Conclusion}

This research examined the differences among terrorists and nonterrorists regarding whether they were convicted at trial or by a plea agreement. Traditionally, about $95 \%$ 
of federal defendants are convicted via a plea agreement. However, results from the current research indicate that a substantially larger percentage of terrorists and nonterrorists matched by lead offense are more likely to go to trial, and ultimately be convicted at trial, than among the general population of federal defendants. Nearly $30 \%$ of the terrorists and $14 \%$ of the nonterrorists were convicted in federal trials. This difference (30\% and $14 \%$ compared to $4 \%$ to $5 \%$ among other federal defendants) suggests that the charges for which the terrorists were tried (and for which the matched sample was based on) were substantially more serious than traditional federal defendants.

Importantly, both terrorists and nonterrorists exhibited similar patterns when the samples were tested separately. Those patterns were largely similar to earlier studies of plea bargaining (e.g., Albonetti, 1990; Meyer \& Gray, 1997), with the exception of the influence of number of counts, which will be discussed shortly.

Of greatest interest is the finding that the terrorists in this study were twice as likely to be convicted at trial as nonterrorists (30\% compared to $14 \%$, respectively), indicating that factors other than those identified in decision-centered studies and studies of traditional legal and extra-legal variables were at work in the terrorist sample. This difference existed in each of the three models tested, despite controls for selected demographic and legal variables.

Other than whether the person was designated as a terrorist, only two additional variables were significant predictors of trial conviction-age and number of counts. Both of these findings are worthy of comment. Unlike conventional wisdom about the demographic characteristics of terrorists, persons indicted in federal courts for terrorism-related activities tend to be considerably older than traditional federal defendants (Corley, Smith, \& Damphousse, 2005). With an average age at indictment of 35 to 40 years, most federally indicted terrorists defy traditional perceptions about federal defendants and the youthfulness of terrorists. Second, we found that the greater the number of counts, the more likely a defendant was to be convicted at trial. This seems contradictory to previous research by Albonetti (1990), who found that the greater the number of counts, the greater the probability of settlement by plea agreement. However, it should be noted that conviction at trial and settlement by plea agreement are not measurements of the same variable. Although the two should be highly related, their subtle differences apparently affect number of counts in substantively different ways. This effect is probably related to sample selectionthat the charges for which the sample of terrorists and nonterrorists were indicted were significantly more serious than typical federal defendants. This notion, however, that severity of charges affects either the decision to go to trial or the trial outcome, deserves continued examination for this class of offenders.

Theoretically, structural-contextual theory provides a plausible explanation: Terrorism results in the emergence of a proactive political environment, which coalesces into a common goal shared by federal investigators and federal prosecutors- the apprehension, arrest, and conviction of terrorists. Similar to the effect on sentencing variance (Smith and Damphousse, 1996, 1998), plea bargaining decreases as political focus and government resources are shifted to combat terrorism. However, the 
development of more precise propositions from which to identify testable hypotheses is necessary to further this line of reasoning.

An inherent weakness of this study is the lack of sentencing commission data on traditional offenders who have been indicted but not convicted. Including that information would allow examination of the broader terrorism population contained in the ATS. This would make possible the analysis of another important factor in this line of research-acquittal rates. Acquittal rates among terrorists appear to be higher than among nonterrorists (see Smith, 1994; Smith \& Damphousse, 1996; Smith, Damphousse, Yang, \& Ginther, 2005) and logically related to plea bargain or trial rates. The decision regarding whether to plead guilty or go to trial and, subsequently, whether one is convicted at trial is the result of a complicated series of interactions reflecting the ideology of the defendant, the manner in which the defendants desire to be portrayed in public, and the manner in which the prosecution desires to portray the defendant before a prospective jury. This area of research is in its infancy and could be of significant use to prosecutors and public defenders alike.

\section{Appendix \\ Coding of Count Severity Variable}

\begin{tabular}{lcc}
\hline & Federal Administrative Office Code & Code for Severity \\
\hline Treason, sedition & 9754 & 29 \\
Murder, $^{\text {st }}$ & 0100 & 28 \\
Kidnapping, hostage $^{\prime}$ & 7611 & 27 \\
Racketeering & 7400 & 26 \\
Explosives & 994 & 25 \\
Firearms & 7380 & 24 \\
Robbery, bank & 1100 & 23 \\
Murder, st, conspiracy $_{\text {Embezzlement, bankruptcy }}$ & 0101 & 22 \\
Counterfeiting & 4990 & 21 \\
Robbery, conspiracy & 5800 & 20 \\
Manslaughter & 1400 & 19 \\
Firearms, machine guns, conspiracy & 0300 & 18 \\
Drugs, cocaine & 7800 & 17 \\
Drugs, distribution marijuana & 6701 & 16 \\
Auto theft & 6501 & 15 \\
Embezzlement, other & 5100 & 14 \\
Theft, bank & 4990 & 13 \\
National defense & 3100 & 12 \\
Racketeering, arson, conspiracy & 9790 & 11 \\
Embezzlement, postal or wire & 7410 & 10 \\
Theft, transportation, conspiracy & 4700 & 9 \\
Escape & 3600 & 8 \\
Aiding escapee & 7312 & 7 \\
\hline
\end{tabular}




\section{Appendix (continued)}

\begin{tabular}{lcc}
\hline & Federal Administrative Office Code & Code for Severity \\
\hline Theft, U.S. property, conspiracy & 3400 & 5 \\
Embezzlement, false claims & 4991 & 4 \\
Firearms, possession & 7820 & 3 \\
Contempt & 9921 & 2 \\
Miscellaneous & 9999 & 1 \\
\hline
\end{tabular}

Note: Code for severity: $1=$ least severe and $29=$ most severe .

\section{Notes}

1. Notable exceptions would be those jurisdictions where plea bargaining has been abolished.

2. Sentencing research is included here because studies invariably test the effect of plea bargains on sentence outcome, and some (e.g., Albonetti, 1998; Kramer \& Ulmer, 1996) contain findings that are salient and should be explored.

3. See McAllister (1990) for a discussion of the impact of eyewitness evidence.

4. See Holmes, Daudistel, and Taggart (1992) for a discussion of the impact of plea bargains on case disposition, partially refuting findings made in earlier studies.

5. Champion reports that of 2,971 cases in his study that went to trial, only 112 involved defendants represented by public defenders (1989).

6. For a discussion of plea bargain rates in lower courts being affected adversely by the seriousness of an offense, see Brickey \& Miller (1975) and Mileski (1971).

7. But see Albonetti (1990), who found that an increase in the number of eyewitnesses exerted a negative effect on pleading guilty.

8. But see Albonetti (1990), whose research reached the opposite conclusion-Black defendants were less likely to plead guilty than White defendants.

9. Only eight defendants had prior convictions.

10. The uncertainty avoidance perspective suggests that prosecutors will increasingly opt for plea bargaining as their perceived chances of winning a case at trial diminish. This is particularly the case where defendants are considered a danger to the community. Prosecutors rationalize that it is better to secure immediate incarceration rather than risking acquittal.

11. After receiving the FBI list, data collection teams visited the federal courthouses and archive facilities to review the identified cases and copy documents. Data gleaned from those documents were then coded into approximately 80 variables and entered into the American Terrorism Study (ATS) database.

12. Defense motions is a variable that measures the number of defense motions filed in a particular case. The database from which the terrorist sample is derived, ATS, also contains the type of defense motions filed (e.g., motions to suppress evidence, etc.).

\section{References}

Albonetti, C. A. (1990). Race and the probability of pleading guilty. Journal of Quantitative Criminology, 6,315 .

Albonetti, C. A. (1998). Direct and indirect effects of case complexity, guilty pleas, and offender characteristics on sentencing for offenders convicted of a white-collar offense prior to sentencing guidelines. Journal of Quantitative Criminology, 14, 353. 
Alschuler, A. (1975). The prosecutor's role in plea bargaining. University of Chicago Law Review, 36, 50.

Brickey, S. L., \& Miller, D. E. (1975). Bureaucratic due process: An ethnography of a traffic court. Social Problems, 22, 688.

Buckle, S., \& Buckle, L. (1977). Bargaining for justice: Case disposition and reform in the criminal courts. New York: Praeger.

Champion, D. J. (1987). District attorneys and plea bargaining: An analysis of the prosecutorial priorities influencing negotiated pleas. Prosecutor, 20, 25.

Champion, D. J. (1989). Private counsels and public defenders: A look at weak cases, prior records, and leniency in plea bargaining. Journal of Criminal Justice, 17, 253.

Corley, S., Smith, B., \& Damphousse, K. (2005). The changing face of American terrorism. In L. Snowden \& B. Whitsel (Eds.) Terrorism: Research, readings, and realities (pp. 49-62).Upper Saddle River, NJ: Prentice Hall.

Damphousse, K. R., \& Smith, B. L. (2004). Terrorism and empirical testing: Using indictment data to assess changes in terrorist conduct. In M. Deflem (Ed.), Terrorism and counter-terrorism: Criminological perspectives (pp. 75-92). Philadelphia: Elsevier Science.

Emmelman, D. S. (1996). Trial by plea bargain: Case settlement as a product of recursive decisionmaking. Law \& Society, 309, 335.

Frazier, C. E., \& Bock, E. W. (1982). Effects of court officials on sentence severity: Do judges make a difference? Criminology, 20, 257.

Hagan, J. (1989a). Structural criminology. New Brunswick, NJ: Rutgers University.

Hagan, J. (1989b). Why is there so little criminal justice theory? Neglected macro- and micro-level links between organization and power. Journal of Research in Crime and Delinquency, 26,116-135.

Hagan, J., Nagel, I., \& Albonetti, C. (1980). The differential sentencing of white-collar offenders in ten federal district courts. American Sociological Review, 45, 802-820.

Harris, R. A., \& Springer, J. F. (1984). Plea bargaining as a game: An empirical analysis of negotiated sentencing decisions. Policy Studies Review, 4(2), 245.

Heumann, M. (1977). Plea bargaining: The experience of prosecutors, judges, and defense attorneys. London: University of Chicago Press.

Holmes, M. D., Daudistel, H. C., \& Taggart, W. A. (1992). Plea bargaining policy and state district court caseloads: An interrupted time series analysis. Law \& Society Review, 26(1), 139.

Klein, J. F. (1976). Inducements to plead guilty: Frontier justice revisited. In P. Wickman \& P. Whitten (Eds.), Readings in criminology. Lexington, MA: D.C. Heath.

Kramer, J. H., \& Ulmer, J. T. (1996). Sentencing disparity and departures from guidelines. Justice Quarterly, 13, 401.

LaFave, W. L. (1978). The prosecutor's discretion in the United States. American Journal of Comparative Law, 18, 532.

LaFree, G. D. (1980). Variables affecting guilty pleas and convictions in rape cases: Toward a social theory of rape processing. Social Forces, 58, 833.

Lagoy, S., Hussey, F., \& Kramer, J. (1979). The prosecutorial function and its relation to determiniate sentencing structures. In W. F. McDonald (Ed.), The prosecutor (pp. 209-238). Beverly Hills, CA: Sage.

Lagoy, S., Senna, J., \& Siegel, L. (1976). An empirical study on information usage for prosecutorial decision making in plea negotiations. American Criminal Law Review, 13, 435.

Mather, L. M. (1979). Plea bargaining or trial? The process of criminal case disposition. Lexington, MA: Lexington Books.

McAllister, H. A. (1990). Effects of eyewitness evidence on plea-bargain decisions by prosecutors and defense attorneys. Journal of Applied Social Psychology, 20, 1461.

McAllister, H. A. \& Bregman, N. J. (2001). Plea bargaining by defendants: A decision theory approach. Journal of Social Psychology, 126, 106.

Meyer, J., \& Gray, T. (1997). Drunk drivers in the courts: Legal and extra-legal factors affecting pleas and sentences. Journal of Criminal Justice, 25, 155. 
Mileski, M. (1971). Courtroom encounters: An observation study of a lower criminal court. Law and Society Review, 5, 473.

Newman, D. (1966). Conviction: The determination of guilt or innocence without trial. Boston, MA: Little, Brown.

Parnas, R. (1979). Empirical data, tentative conclusions, and difficult questions about plea bargaining in three California counties. Federal Probation, 22, 12.

Simon, H. (1976). Administrative behavior. New York: Free Press.

Smith, B. L. (1994). Terrorism in America: Pipe bombs and pipe dreams. Albany: State of University New York Press.

Smith, B. L., Damphousse, K., Yang, S., \& Ginther, C. (2005). Prosecuting politically motivated offenders: The impact of the "terrorist" label on criminal case outcomes. International Journal of Contemporary Sociology, 42, 209-226.

Smith, B. L., \& Damphousse, K. R. (1996). Punishing political offenders: The effect of political motive on federal sentencing decisions. Criminology, 34, 289.

Smith, B. L., \& Damphousse, K. R. (1998). Terrorism, politics, and punishment: A test of structural contextual theory and the "liberation hypothesis." Criminology, 36, 67-92.

Utz, P. (1977). Settling the facts. Lexington, MA: Heath/Lexington.

White. L. (1971). A proposal for reform of the plea bargaining process. University of Pennsylvania Law Review, 119, 437.

Wooldredge, J. D. (1989). The impact of jurisdiction size on guilty plea rates in 569 state courts. Sociology and Social Research, 74, 26.

Worden, A. P. (1990). Policymaking by the prosecutors: The use of discretion in regulating plea bargaining. Judicature, 73, 335.

Christopher A. Shields, JD, is an attorney currently serving as a research associate in the Center for Terrorism Research in Fulbright College in the Department of Sociology and Criminal Justice at the University of Arkansas. At the time this article was written, he was a completing coursework toward a $\mathrm{PhD}$ in public policy and serving as data manager on "The American Terrorism Study."

Kelly R. Damphousse, $\mathrm{PhD}$, serves as an associate dean the College of Arts and Sciences at the University of Oklahoma, where he is also an associate professor in the Department of Sociology. His research interests include terrorism, homicide, and the drugs and crime nexus. He has been associate director of "The American Terrorism Study" since 1994. From 1998 to 2004, he was the site director of the National Institute of Justice-funded Arrestee Drug Abuse Monitoring Program for Oklahoma City and Tulsa.

Brent L. Smith, $\mathrm{PhD}$, is a professor in the Department of Sociology and Criminal Justice at the University of Arkansas. He is the director of the Center for Terrorism Research in Fulbright College and manages research projects sponsored by the National Institute of Justice and the National Memorial Institute for the Prevention of Terrorism in Oklahoma City. He has directed "The American Terrorism Study" since 1988. He is the author of Terrorism in America: Pipe Bombs and Pipe Dreams (1994) and has testified on domestic terrorism on several occasions before the U.S. House of Representatives Judiciary Subcommittee on Crime. His publications on terrorism have appeared in Criminology, Criminology \& Public Policy, Justice Quarterly, and other scholarly outlets. 